\author{
Marquette University \\ e-Publications@Marquette
}

Biomedical Sciences Faculty Research and

Publications

Biomedical Sciences, Department of

$1-2016$

\title{
CB1 Receptor Antagonism Blocks Stress-Potentiated Reinstatement of Cocaine Seeking in Rats
}

Jayme R. McReynolds

Marquette University, jayme.mcreynolds@marquette.edu

Elizabeth M. Doncheck

Marquette University

Oliver Vranjkovic

Marquette University

Geoffrey S. Ganzman

Marquette University

David A. Baker

Marquette University, david.baker@marquette.edu

See next page for additional authors

Follow this and additional works at: https://epublications.marquette.edu/biomedsci_fac

Part of the Neurosciences Commons

\section{Recommended Citation}

McReynolds, Jayme R.; Doncheck, Elizabeth M.; Vranjkovic, Oliver; Ganzman, Geoffrey S.; Baker, David A.; Hillard, Cecilia J.; and Mantsch, John R., "CB1 Receptor Antagonism Blocks Stress-Potentiated Reinstatement of Cocaine Seeking in Rats" (2016). Biomedical Sciences Faculty Research and Publications. 152.

https://epublications.marquette.edu/biomedsci_fac/152 


\section{Authors}

Jayme R. McReynolds, Elizabeth M. Doncheck, Oliver Vranjkovic, Geoffrey S. Ganzman, David A. Baker, Cecilia J. Hillard, and John R. Mantsch

This article is available at e-Publications@Marquette: https://epublications.marquette.edu/biomedsci_fac/152 


\title{
CB1 Receptor Antagonism Blocks Stress-Potentiated Reinstatement of Cocaine Seeking in Rats
}

\author{
Jayme R. McReynolds \\ Department of Biomedical Sciences, Marquette University, \\ Milwaukee, WI \\ Elizabeth M. Doncheck \\ Department of Biomedical Sciences, Marquette University, \\ Milwaukee, WI \\ Oliver Vranjkovic \\ Department of Biomedical Sciences, Marquette University, \\ Milwaukee, WI \\ Geoffrey S. Ganzman \\ Department of Biomedical Sciences, Marquette University, \\ Milwaukee, WI \\ David A. Baker \\ Department of Biomedical Sciences, Marquette University, \\ Milwaukee, WI \\ Cecilia J. Hillard \\ Department of Pharmacology and Toxicology and Neuroscience \\ Research Center, Medical College of Wisconsin, \\ Milwaukee, WI \\ Psychopharmacology, Vol 233, No. 1 (January 2016): pg. 99-109. DOI. This article is (C Springer-Verlag Berlin Heidelberg \\ and permission has been granted for this version to appear in e-Publications@Marquette. Springer-Verlag Berlin \\ Heidelberg does not grant permission for this article to be further copied/distributed or hosted elsewhere without the \\ express permission from Springer-Verlag Berlin Heidelberg.
}


NOT THE PUBLISHED VERSION; this is the author's final, peer-reviewed manuscript. The published version may be accessed by following the link in the citation at the bottom of the page.

\author{
John R. Mantsch \\ Department of Biomedical Sciences, Marquette University, \\ Milwaukee, WI
}

\begin{abstract}
Rationale: Under some conditions stress, rather than directly triggering cocaine seeking, potentiates reinstatement to other stimuli, including a subthreshold cocaine dose. The mechanisms responsible for stress-potentiated reinstatement are not well-defined. Endocannabinoid signaling is increased by stress and regulates synaptic transmission in brain regions implicated in motivated behavior.

Objectives: To test the hypothesis that cannabinoid receptor 1 (CB1R) signaling is required for stress-potentiated reinstatement of cocaine seeking in rats.

Methods: Following i.v. cocaine self-administration ( $2 \mathrm{hr}$ access/day) and extinction in male rats, footshock stress alone does not reinstate cocaine seeking, but reinstatement is observed when footshock is followed by an injection of an otherwise subthreshold dose of cocaine $(2.5 \mathrm{mg} / \mathrm{kg}$, i.p. $)$. $\mathrm{CB} 1 \mathrm{R}$ involvement was tested by systemic administration of the CB1R antagonist $\mathrm{AM} 251(0,1$, or $3 \mathrm{mg} / \mathrm{kg}$, i.p.) prior to testing for stresspotentiated reinstatement.

Results: Stress-potentiated reinstatement was blocked by both 1 and 3 $\mathrm{mg} / \mathrm{kg}$ AM251. By contrast, AM251 only attenuated food-reinforced lever pressing at the higher (i.e., $3 \mathrm{mg} / \mathrm{kg}$ ) dose and did not affect locomotor activity at either dose tested. Neither high-dose cocaine-primed reinstatement $(10 \mathrm{mg} / \mathrm{kg}$, i.p.) nor footshock stress-triggered reinstatement following longaccess cocaine self-administration ( $6 \mathrm{hr}$ access/day) were affected by AM251 pretreatment. Footshock stress increased concentrations of both endocannabinoids, $\mathrm{N}$-arachidonylethanolamine and 2-arachidonoylglycerol, in regions of the prefrontal cortex.

Conclusions: These findings demonstrate that footshock stress increases prefrontal cortical endocannabinoids and stress-potentiated reinstatement is CB1R-dependent, suggesting that CB1R is a potential therapeutic target for relapse prevention, particularly in individuals whose cocaine use is stressrelated.
\end{abstract}

Keywords: addiction, cocaine, stress, reinstatement, relapse, endocannabinoid, self-administration

Psychopharmacology, Vol 233, No. 1 (January 2016): pg. 99-109. DOI. This article is (C Springer-Verlag Berlin Heidelberg and permission has been granted for this version to appear in e-Publications@Marquette. Springer-Verlag Berlin Heidelberg does not grant permission for this article to be further copied/distributed or hosted elsewhere without the express permission from Springer-Verlag Berlin Heidelberg. 
NOT THE PUBLISHED VERSION; this is the author's final, peer-reviewed manuscript. The published version may be accessed by following the link in the citation at the bottom of the page.

\section{Introduction}

The sudden and often unpredictable relapse to drug use that can emerge even after prolonged periods of drug abstinence is a major obstacle to the effective long-term management of substance abuse. The ability to prevent relapse has been hindered by an imprecise and incomplete understanding of situations that lead to the re-emergence of drug-seeking behavior and the underlying neurobiological processes.

Stress plays a particularly problematic role in drug relapse (McReynolds et al. 2014; Shaham et al. 2000) as it is prevalent and unavoidable in daily life. While it is evident that stress contributes to relapse, the manner in which it does so appears to be more complex than simply triggering use. For example, while clinical laboratory studies have found that stress imagery can trigger craving (Sinha 2009), self-reports by addicts regarding the role of stress in their drug use are suggestive of a less direct relationship between stress and relapse (Furnari et al. 2015; Preston and Epstein 2011). Consistent with this more nuanced role for stress, others have reported that stress may interact with other relapse triggers to promote drug use (Coffey et al. 2002; De La Garza et al. 2009; Duncan et al. 2007). These reports parallel findings from preclinical studies showing that acute stressors can potentiate reinstatement induced by cocainerelated cues in rats (Buffalari and See 2009; Feltenstein and See 2006).

Previous studies from our laboratory have demonstrated that the ability of intermittent electric footshock to reinstate extinguished cocaine seeking in rats can vary depending on the prior history of cocaine use. We have identified conditions under which rats with a history of extended access cocaine self-administration $(14 \times 6$ hrs/day) show robust footshock-triggered reinstatement of cocaine seeking following extinction, while rats that have a history of more limited daily access ( $14 \times 2 \mathrm{hrs} /$ day) do not (Mantsch et al. 2008a). However, although footshock stress does not directly reinstate cocaine seeking following self-administration under these short-access conditions, it can amplify the effects of an otherwise sub-threshold priming injection of cocaine (2.5 mg/kg; Graf et al. 2013), thereby 
potentiating reinstatement. We have proposed that this potentiating effect of footshock stress reflects its role in many drug users in whom stress appears to "set the stage" for cocaine use. In contrast to the relapse-triggering effects of stress, which have been extensively studied, relatively little is known about the neurobiological mechanisms that underlie these stage-setting effects of stress.

We recently reported that stress-potentiated reinstatement, unlike stress-triggered reinstatement (Mantsch et al. 2008a), is corticosterone-dependent, and that elevated corticosterone is sufficient to reproduce the potentiating effect of stress (Graf et al. 2013). Moreover, we found that one corticosterone-dependent mechanism through which stress potentiates cocaine-induced reinstatement involves reduced dopamine clearance in the nucleus accumbens by the glucocorticoid-sensitive organic cation transporter 3 (OCT3; Graf et al. 2013). Endocannabinoid (eCB) signaling represents a second corticosterone-dependent mechanism through which stress could potentiate cocaine-induced reinstatement. Both stress and corticosterone increase $\mathrm{eCB}$ levels in brain regions that have been implicated in drug-seeking behavior, most notably the prefrontal cortex (PFC) and nucleus accumbens (NAc; Hill et al. 2011; Rademacher et al. 2008). In the brain, the CB1Rs are thought to represent the primary targets for eCB signaling (Devane et al. 1988; Egertova et al. 1998; Herkenham et al. 1991; Howlett et al. 2002; Pertwee 1997; Pertwee and Ross 2002), although CB2R-mediated effects have been reported (Brusco et al. 2008; Onaivi 2011; Onaivi et al. 2006). As CB1Rs have been proposed to play a critical role in both drug addiction (Sidhpura and Parsons 2011) and adaptation to stress (Hill et al. 2010), we hypothesize that stress potentiation of cocaineinduced reinstatement requires eCB signaling through CB1Rs. In the present study we test this hypothesis by assessing the effects of the CB1R antagonist, AM251, on stress-potentiated reinstatement.

\section{Methods}

\section{Subjects}

Male Sprague-Dawley rats (275-300 g at arrival), obtained from Harlan Laboratories, were individually housed in a humidity- and 
temperature-controlled AAALAC-accredited facility with food and water available ad libitum. Rats were maintained on a $12 \mathrm{~h} / 12 \mathrm{~h}$ reverse light/dark cycle (0700-1900 lights off) and all behavioral procedures were conducted during the dark phase of the light cycle. All experimental procedures were carried out in compliance with National Institutes of Health guidelines and were approved by the Institutional Animal Care and Use Committee (Marquette University).

\section{Catheter implantation}

For intravenous self-administration and reinstatement testing, each rat was anesthetized with ketamine $\mathrm{HCl}(100 \mathrm{mg} / \mathrm{kg}$, i.p.) and xylazine (2 mg/kg, i.p.) and had an indwelling silicon (Silastic; Dow Corning; $0.64 \mathrm{~mm}$ i.d.; $1.19 \mathrm{~mm}$ o.d.) catheter implanted into the jugular vein. Catheters were connected to back mount cannulae (Plastics One) attached to monofilament surgical mesh (Atrium Medical). When placed in the operant chambers, the back mount cannulae was connected to PE tubing ( $0.51 \mathrm{~mm}$ i.d. $\times 1.52 \mathrm{~mm}$ o.d.) encased in stainless-steel spring leashes (Plastics One). The PE tubing was connected via a fluid swivel (Instech Lab) suspended above the self-administration chamber and Tygon tubing (VWR; $0.51 \mathrm{~mm}$ i.d. $\times$ $1.52 \mathrm{~mm}$ o.d.) to syringes in pumps (Razel) outside of the operant chamber. Rats received ibuprofen in their drinking water for 3 days following surgery and were given iv antibiotic treatment for at least 5 days. The rats were allowed to recover for 1 week before the initiation of self-administration training.

\section{Cocaine Self-Administration}

Self-administration/reinstatement procedures were conducted in computer-interfaced operant conditioning chambers equipped with retractable levers and stimulus lights above each lever in soundattenuating cubicles (MED-Associates). Following recovery from surgery, rats were trained to self-administer cocaine (0.5 $\mathrm{mg} / \mathrm{kg} /$ infusion) by pressing a lever under a fixed-ratio (FR) 1 schedule during daily $2-\mathrm{h}$ sessions. Pressing the lever resulted in an infusion ( $200 \mu \mathrm{L}$ over $5 \mathrm{~s}$ ) followed by a $10 \mathrm{~s}$ time-out period during which lever presses were recorded but not reinforced and the stimulus light above the lever was extinguished. Responding on a second lever, 
the inactive lever, was also recorded, but not reinforced. Following stable responding, the FR value was increased gradually to FR4. Once stable responding on FR4 was achieved ( $<10 \%$ change over 3 days), rats were allowed to self-administer cocaine daily for 14 additional days.

\section{Extinction and reinstatement}

After 14 days of cocaine self-administration, rats underwent extinction training which was identical to cocaine self-administration with the exception that the cocaine was replaced with saline. Rats underwent daily $2-\mathrm{h}$ extinction training sessions until they met the extinction criterion ( $<15$ lever presses $/ 2 \mathrm{~h}$ ). Once rats met this criterion, a reinstatement test was given the next day. Aside from footshock and/or cocaine pre-exposure, reinstatement sessions were otherwise identical to extinction conditions. All rats underwent multiple reinstatement tests within each experiment in a counterbalanced fashion. Each rat received a maximum of 4 reinstatement tests. Rats were given additional extinction/washout sessions between reinstatement tests until they reached criterion ( $<15$ lever presses $/ 2$ h) before receiving additional reinstatement tests.

\section{Experiment 1: Effect of CB1R antagonism on stress- potentiated reinstatement of cocaine seeking}

Under the self-administration parameters used in the present study $(0.5 \mathrm{mg} / \mathrm{kg} / \mathrm{inf} ; 14 \times 2 \mathrm{hrs} /$ day $)$, we have found previously that footshock alone does not trigger reinstatement of extinguished cocaine seeking, but potentiates reinstatement in response to an injection of an otherwise subthreshold dose of cocaine $(2.5 \mathrm{mg} / \mathrm{kg}$, i.p.; Graf et al. 2013). Following self-administration and extinction, all rats were tested for reinstatement under each of the following conditions, in counter-balanced sequence: 1 ) no footshock/cocaine; 2) footshock/saline; and 3) footshock/cocaine following 30-min pretreatment with the CB1R antagonist, AM251 (1 or $3 \mathrm{mg} / \mathrm{kg}$, i.p.), or vehicle (1:1:18 ethanol: Cremaphor: saline). Separate sets of rats were used for each dose of AM251 so each rat received 4 reinstatement tests total. Intermittent electric footshock $(3 \times 0.5 \mathrm{~mA}$, 200 ms duration, mean intershock interval 40s, range 10-70s over a

Psychopharmacology, Vol 233, No. 1 (January 2016): pg. 99-109. DOI. This article is (C Springer-Verlag Berlin Heidelberg and permission has been granted for this version to appear in e-Publications@Marquette. Springer-Verlag Berlin Heidelberg does not grant permission for this article to be further copied/distributed or hosted elsewhere without the express permission from Springer-Verlag Berlin Heidelberg. 
15 min period) was delivered through the stainless-steel grid floors of the operant conditioning chambers immediately prior to cocaine ( 2.5 $\mathrm{mg} / \mathrm{kg}$, i.p.) or saline $(0.9 \% \mathrm{NaCl})$ injections followed by the $2-\mathrm{h}$ reinstatement test sessions.

\section{Experiment 2: Effect of CB1R antagonism on cocaine- primed and stress-triggered reinstatement of cocaine seeking}

We have previously reported that stress-potentiated reinstatement is mediated in part by a mechanism that is distinct from that involved in either stress-triggered or cocaine-primed reinstatement; stress-potentiated reinstatement is corticosteronedependent (Graf et al. 2013), while stress-triggered and cocaineprimed reinstatement are not (Erb et al. 1998; Graf et al. 2011; Mantsch et al., 2008b). To determine if CB1R involvement is also selective for stress-potentiated cocaine seeking, we tested separate groups of rats for the effects of AM251 on cocaine-primed and stresstriggered reinstatement.

To test for the effect of AM251 on cocaine-primed reinstatement, rats underwent cocaine self-administration and extinction as described above, but were given a systemic injection of a dose of cocaine $(10 \mathrm{mg} / \mathrm{kg}$, i.p) which has been reported to reliably reinstate cocaine seeking (Mantsch et al. 2008b; Mantsch and Goeders 1999; Mantsch et al. 2004), or saline immediately prior to the start of the 2-h reinstatement session. As above, rats were pretreated with AM251 (1, $3 \mathrm{mg} / \mathrm{kg}$, ip) or vehicle (1:1:18 ethanol: Cremaphor: saline) $30 \mathrm{~min}$ prior to the start of the reinstatement test. Each rat was tested for reinstatement under each of the following conditions in counterbalanced condition: 1) vehicle/saline; 2) vehicle/cocaine; 3) AM251/cocaine. Rats were given extinction/washout sessions between reinstatement tests until they reached criterion $(<15$ lever presses $/ 2$ h) before receiving additional reinstatement tests. Each rat received all reinstatement tests in a counterbalanced order and received a total of 3 reinstatement tests.

To determine if CB1R activation represents a distinct mechanism that underlies the ability of stress to potentiate, rather than directly trigger induce reinstatement, we tested a separate group of rats for 
the effect of AM251 under conditions in which footshock stress alone can trigger reinstatement of extinguished cocaine seeking. We have previously shown that delivery of footshock alone produces reliable and robust reinstatement of cocaine seeking in rats with a history of longer daily access to cocaine self-administration ( $6 \mathrm{hrs} /$ day; Mantsch et al. 2008a; Blacktop et al. 2011; Vranjkovic et al. 2014). In these experiments, rats were provided with daily long access ( $6 \mathrm{hr} /$ day $\times 14$ days) to cocaine $(0.5 \mathrm{mg} / \mathrm{kg} / \mathrm{inf})$ for self-administration prior to extinction (as described above) and testing for footshock stresstriggered reinstatement (same footshock conditions as above). To test for CB1R involvement in stress-triggered reinstatement, rats were pretreated with either AM251 (1 mg/kg, ip) or vehicle (1:1:18 ethanol: Cremaphor: saline) 30 min prior to delivery of footshock followed by reinstatement testing. Each rat was tested under the following reinstatement conditions, in a counterbalanced order: 1) vehicle/no footshock; 2) vehicle/footshock; 3) AM251/no footshock; 4) AM251/footshock. Rats were given extinction/washout sessions between reinstatement tests until they reached criterion $(<15$ lever presses $/ 2 \mathrm{~h}$ ) before receiving additional reinstatement tests. Each rat received a total of 4 reinstatement tests and was required to once again meet the extinction criterion ( $<15$ lever presses/ $2 \mathrm{~h}$ ) between tests.

\section{Experiment 3: Effect of CB1R antagonism on responding for food and basal locomotor activity}

Although the lack of AM251 effects on cocaine-primed and stress-triggered reinstatement suggests that the effects of the drug on stress-potentiated reinstatement were not secondary to non-specific motor suppression, we decided to further address this possibility by testing a separate group of rats for AM251 effects on food-reinforced responding and locomotor activity. When testing for effects on foodreinforced behavior, rats were food deprived to $90 \%$ of their starting body weight and trained to press a lever under a FR4 schedule of sucrose-sweetened food pellet ( $45 \mathrm{mg}$; BioServ) reinforcement during daily 30-min sessions. Drug effects were tested once stable responding was achieved ( $<10 \%$ change over 3 days). AM251 ( $1,3 \mathrm{mg} / \mathrm{kg}$, ip) or vehicle (1:1:18 ethanol: Cremaphor: saline) was administered $30 \mathrm{~min}$ prior to the start of the session. Each rat received vehicle and both 
doses of AM251 in a counterbalanced order for a total of 3 tests. Rats were given additional days between drug tests to ensure that stable food responding was once again achieved before the next test.

As there is strong evidence for a role of endocannabinoids in feeding, metabolism, and obesity (Bellocchio et al. 2006; Kirkham and Tucci 2006; Silvestri and Di Marzo 2013), food responding alone may not be the most accurate measurement of CB1R antagonist effects on motor activity. Therefore, the effect of AM251 on basal locomotor behavior was also determined. Locomotor activity was measured in the home cages of the rats using an automated activity system (AccuScan Instruments, Inc., Columbus, $\mathrm{OH}$ ) consisting of photocell-containing frames, equipped with sensor panels containing 16 photo beams in a horizontal orientation, into which cages could be placed for recording. Both total (total photobeam breaks) and ambulatory (consecutive photobeam) breaks activity counts were recorded using a computer interfaced MicroMax software-based system (AccuScan Instruments). Prior to testing for drug effects, rats received 3 days of systemic i.p. saline injections to habituate them to injections and limit the contribution of novelty/injection stress-related effects. Thereafter, all rats were tested for effects of AM251 ( 1 and $3 \mathrm{mg} / \mathrm{kg}$, ip) and vehicle ( $1: 1: 18$ ethanol: Cremaphor: saline) in a counterbalanced sequence with washout days between each test. Locomotor activity was recorded for one hour starting immediately post-injection.

\section{Experiment 4: Effect of footshock stress on endocannabinoid content in the medial prefrontal cortex}

The medial prefrontal cortex (mPFC) is critical for cocaine seeking in response to multiple reinstating stimuli, including footshock and cocaine (McFarland et al. 2004). Subregions of the MPFC (e.g., prelimbic, infralimbic cortices, anterior cingulate) appear to have differential roles in reinstatement following exposure to stress (Capriles et al. 2003) or cocaine (Capriles et al. 2003; Peters et al. 2008). While it has been reported that stress can increase endocannabinoid content in the MPFC (Hill et al. 2011), most studies examining the effect of stress on eCB content have utilized acute restraint or forced swim as stressors (Hill et al. 2011; McLaughlin et al. 2012; Rademacher et al. 2008; Roberts et al. 2012). We conducted a preliminary analysis of the effects of footshock stress on eCB content

Psychopharmacology, Vol 233, No. 1 (January 2016): pg. 99-109. DOI. This article is @ Springer-Verlag Berlin Heidelberg and permission has been granted for this version to appear in e-Publications@Marquette. Springer-Verlag Berlin Heidelberg does not grant permission for this article to be further copied/distributed or hosted elsewhere without the express permission from Springer-Verlag Berlin Heidelberg. 
in subregions of the MPFC in rats with no history of cocaine selfadministration. Rats were handled for $2 \mathrm{~min} /$ day for 3 days prior to exposure to the footshock. On the day of testing, rats were transported to the experimental room 1-h prior to administration of footshock stress. Rats were placed into the operant conditioning chambers and received the same 15-min footshock stress that was administered during reinstatement testing: control rats were placed in the operant chambers for 15 min but did not receive the stressor.

Immediately after the 15-min footshock session, rats were placed back into their home cages and 15 min later were rapidly decapitated under isoflurane anesthesia (30-s exposure) for tissue collection. Brains were rapidly removed ( 2.5 min total time) and flash frozen by submersion in liquid nitrogen for $25 \mathrm{~s}$ and then stored at $-80^{\circ} \mathrm{C}$.

For tissue dissection, $1 \mathrm{~mm}$ prefrontal cortical sections (approx. $3.72 \mathrm{~mm}$ to $-2.76 \mathrm{~mm}$ from Bregma) were isolated from coronal sections on dry ice. Prefrontal cortical subregions (prelimbic (PL), infralimbic (IL), and anterior cingulate cortices (AC)) were dissected bilaterally using a scalpel blade, weighed and collected in a microcentrifuge tube and stored at $-80^{\circ} \mathrm{C}$. Subregions from two animals were pooled for each data point.

\section{Endocannabinoid Liquid Chromatography/Mass Spectrometry}

Concentrations of the endocannabinoids $\mathrm{N}$ arachidonylethanolamine (AEA) and 2-arachidonylglycerol (2-AG) were extracted from tissue using a protocol adapted from Patel et al. 2003. Briefly, tissue samples were homogenized in $2 \mathrm{~mL}$ of acetonitrile with $84 \mathrm{pmol}\left[{ }^{2} \mathrm{H}_{8}\right]$ AEA and $186 \mathrm{pmol}\left[{ }^{2} \mathrm{H}_{8}\right] 2-\mathrm{AG}$ using glass rods. Samples were sonicated for $60 \mathrm{~min}$ and frozen overnight at $-20^{\circ} \mathrm{C}$ to precipitate proteins. The supernatant was obtained following centrifugation at $1500 \times g$ for 2 min at $4^{\circ} \mathrm{C}$, was dried under $\mathrm{N}_{2}$ and the lipids were resuspended in methanol. The two endocannabinoids were isolated and quantified by liquid chromatography-electrospray ionization-mass spectrometry (LC-ESI-MS; Agilent LC-MSD 1100 series) and quantified by isotope dilution as described previously (Patel et al. 2003). 
NOT THE PUBLISHED VERSION; this is the author's final, peer-reviewed manuscript. The published version may be accessed by following the link in the citation at the bottom of the page.

\section{Drugs}

Cocaine $\mathrm{HCl}$ was obtained from the National Institute on Drug Abuse (NIDA) through the NIDA Drug Supply Program. The CB1R antagonist AM251 was purchased from Sigma-Aldrich. Cocaine was dissolved in saline ( $0.9 \%$ bacteriostatic saline). AM251 was dissolved first in ethanol, followed by Cremaphor and finally by saline $(0.9 \%$ bacteriostatic saline) in a $1: 1: 18$ ratio.

\section{Statistical Analysis}

Statistical analyses were conducted using SPSS statistics software and consisted of one- or two-way repeated measures ANOVA followed, when appropriate, with post-hoc testing using Bonferronicorrected t-tests. For all analyses, statistical significance was defined as $p<0.05$.

\section{Results}

The numbers of cocaine infusions and responses during the selfadministration and extinction sessions for each reinstatement experiment are shown in Table 1. Rats showed consistent responding during self-administration between self-administration day 1 and 14 in experiments 1 and 2 . Following completion of cocaine selfadministration, rats showed a reduction in lever presses across extinction sessions in both experiments and took an average of $7.67 \pm$ 1.38 extinction sessions before reaching criteria.

Table 1. Cocaine self-administration and extinction responding

\section{Experiment no. (n) Cocaine SA}

\section{Extinction}

\section{SA Day 1 SA Day 14}

$1 \mathrm{ShA} ;(12)$

$2 \mathrm{ShA} ;(8)$

$\operatorname{LgA} ;(5)$
$121.4 \pm 7.5 \quad 126.8 \pm 7.8 \quad 75.9 \pm 7.29 .9 \pm 1.0$

$117.3 \pm 10.6120 .0 \pm 11.0 \quad 77.4 \pm 19.39 .1 \pm 1.8$

$317.8 \pm 34.2396 .0 \pm 12.54166 .8 \pm 41.27 .6 \pm 2.6$

Data represent total active lever responses/2-h session \pm SEM for experiments 1 and 2 for short access (ShA) experiments, and lever responses/6-hr session \pm SEM for experiment 2 for long-access ( $\mathrm{LgA})$ experiments during days 1 and 14 of cocaine selfadministration (SA) and total active lever responses/2-h session \pm SEM on the first day of extinction (Ext) and the last day of extinction before reinstatement testing for experiments 1 and 2 .

Psychopharmacology, Vol 233, No. 1 (January 2016): pg. 99-109. DOI. This article is (C Springer-Verlag Berlin Heidelberg and permission has been granted for this version to appear in e-Publications@Marquette. Springer-Verlag Berlin Heidelberg does not grant permission for this article to be further copied/distributed or hosted elsewhere without the express permission from Springer-Verlag Berlin Heidelberg. 


\section{Experiment 1: Effect of CB1R antagonism on stress-potentiated reinstatement of cocaine seeking}

To confirm that stress produced a potentiation of cocaineinduced reinstatement, as previously described (Graf et al. 2013) we initially compared reinstatement following administration of the footshock/cocaine combination with reinstatement following footshock/saline or administration of cocaine alone (no footshock/cocaine) only in rats pretreated with the vehicle for AM251 (1:1:18 ethanol: Cremaphor: saline). As previously reported in rats tested under the same self-administration conditions (Graf et al. 2013), neither low-dose cocaine $(2.5 \mathrm{mg} / \mathrm{kg}$, i.p.) nor footshock alone reinstated cocaine seeking. However, robust reinstatement was observed when the two stimuli were combined (Fig. 1). A two-way repeated measures ANOVA showed significant main effects of reinstatement testing (extinction vs. reinstatement; $F(1,22)=45.26$, $\mathrm{p}<0.001$ ) and reinstatement condition (footshock/saline, no footshock/cocaine, footshock/cocaine; $F(2,22)=24.42, p<0.001$ ) and a significant interaction between the reinstatement day and reinstatement condition $(F(2,22)=25.52, p<0.001)$. Post-hoc testing revealed significant reinstatement (compared to extinction responses) following delivery of the footshock/cocaine combination $(p<0.001)$ but not with footshock/saline or cocaine alone. Moreover, while no differences in extinction responding were observed across treatment conditions, responding during the reinstatement session that followed delivery of the footshock/cocaine was increased compared to responding following footshock/saline or cocaine alone $(p<0.001)$. 


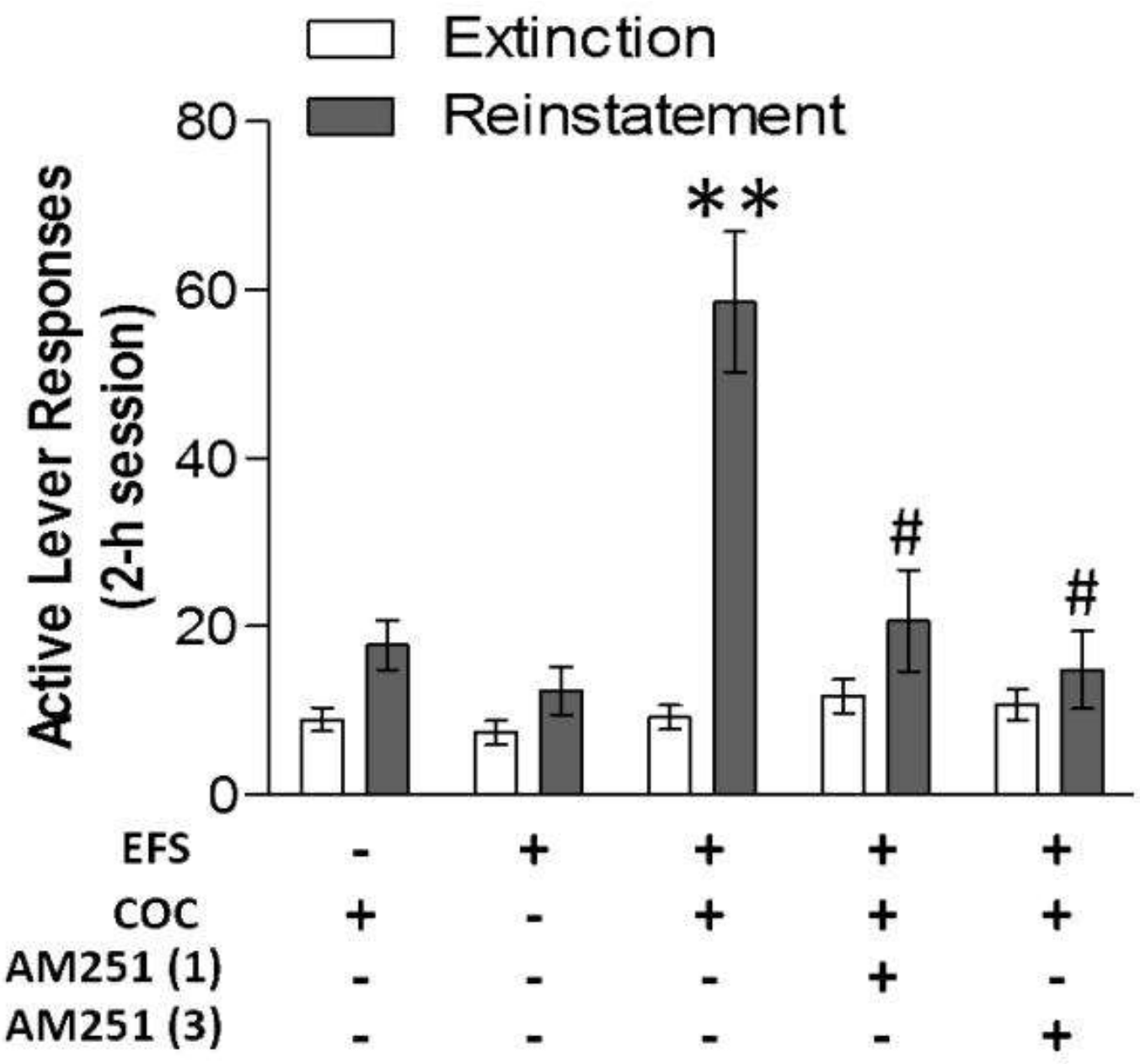

Figure 1. Stress-potentiated reinstatement is CB1R-dependent. Data represent mean active lever responses ( \pm SEM) during 2-h extinction and reinstatement tests. Stresspotentiated reinstatement is observed when rats are exposed to a stressor, $15 \mathrm{~min}$ intermittent electric footshock stress (EFS) followed immediately by a subthreshold dose of cocaine (COC, $2.5 \mathrm{mg} / \mathrm{kg}$, i.p.; **p<.01, compared to reinstatement). Stresspotentiated reinstatement is blocked by pre-treatment with the CB1R antagonist AM251 $(1(n=6), 3(n=6) \mathrm{mg} / \mathrm{kg}$, i.p. $) 30$ min prior to the reinstatement test $(\# p<.05$ compared to Veh/EFS/COC).

The effects of $1 \mathrm{mg} / \mathrm{kg} \mathrm{AM} 251$ and vehicle (Veh) and $3 \mathrm{mg} / \mathrm{kg}$ AM251 and vehicle were assessed in different groups of rats, so a separate 2-way repeated measures (footshock/cocaine x AM251 pretreatment) ANOVA was conducted for each dose. Both doses of AM251 prevented stress-potentiated reinstatement. For $1 \mathrm{mg} / \mathrm{kg}$ AM251 doses, 2-way repeated measures ANOVA showed an overall significant effect of reinstatement (Extinction vs. Reinstatement; 1 $\mathrm{mg} / \mathrm{kg}: \mathrm{F}(1,5)=26.86, \mathrm{p}<0.01$ ), but not drug (Veh vs. AM251; $F(1,5)=5.03, p=0.08)$ and a significant interaction between the 
reinstatement day and drug $(F(1,5)=9.74, p<0.05)$. Post-hoc testing showed that reinstatement was observed in Veh-pretreated $(p<0.05)$, but not AM251 pretreated rats and that reinstatement following vehicle pretreatment was significantly increased relative to reinstatement following AM251 $(\mathrm{p}<0.05)$. Similarly, for the $3 \mathrm{mg} / \mathrm{kg}$ AM251 dose, 2way repeated measures ANOVA revealed significant overall effects of reinstatement testing $(F(1,5)=14.02, p<0.05)$ and $A M 251$ pretreatment $(F(1,5)=12.18, p<0.05)$ and a significant reinstatement $x$ pretreatment interaction $(F(1,5)=18.24, p<0.01)$. As with the lower dose, post-hoc testing demonstrated that reinstatement was observed in Veh-pretreated rats $(p<0.05)$, but not rats pretreated with $3 \mathrm{mg} / \mathrm{kg}$ AM251 and that reinstatement following vehicle pretreatment was significantly increased relative to reinstatement following $3 \mathrm{mg} / \mathrm{kg}$ AM251 $(p<0.05)$.

\section{Experiment 2: Effect of CB1R antagonism on cocaine-primed and stress-triggered reinstatement of cocaine seeking}

In contrast to stress-potentiated cocaine-induced reinstatement, AM251 did not prevent reinstatement in response to a $10 \mathrm{mg} / \mathrm{kg}$ i.p. priming dose of cocaine (Fig. 2A). Effects of pretreatment with 1 $\mathrm{mg} / \mathrm{kg}$ and $3 \mathrm{mg} / \mathrm{kg}$ AM251 on cocaine-primed reinstatement were tested in separate groups of rats. In both cases 2-way repeated measures reinstatement (reinstatement vs. extinction) $x$ drug pretreatment (AM251 vs. Veh) ANOVA revealed overall reinstatement effects $\left(F_{(1,7)}=18.62, p<0.001\right.$ and $\left.F_{(1,7)}=25.51, p<0.01\right)$ but not overall effects of AM251 and no reinstatement $x$ AM251 pretreatment interactions. 

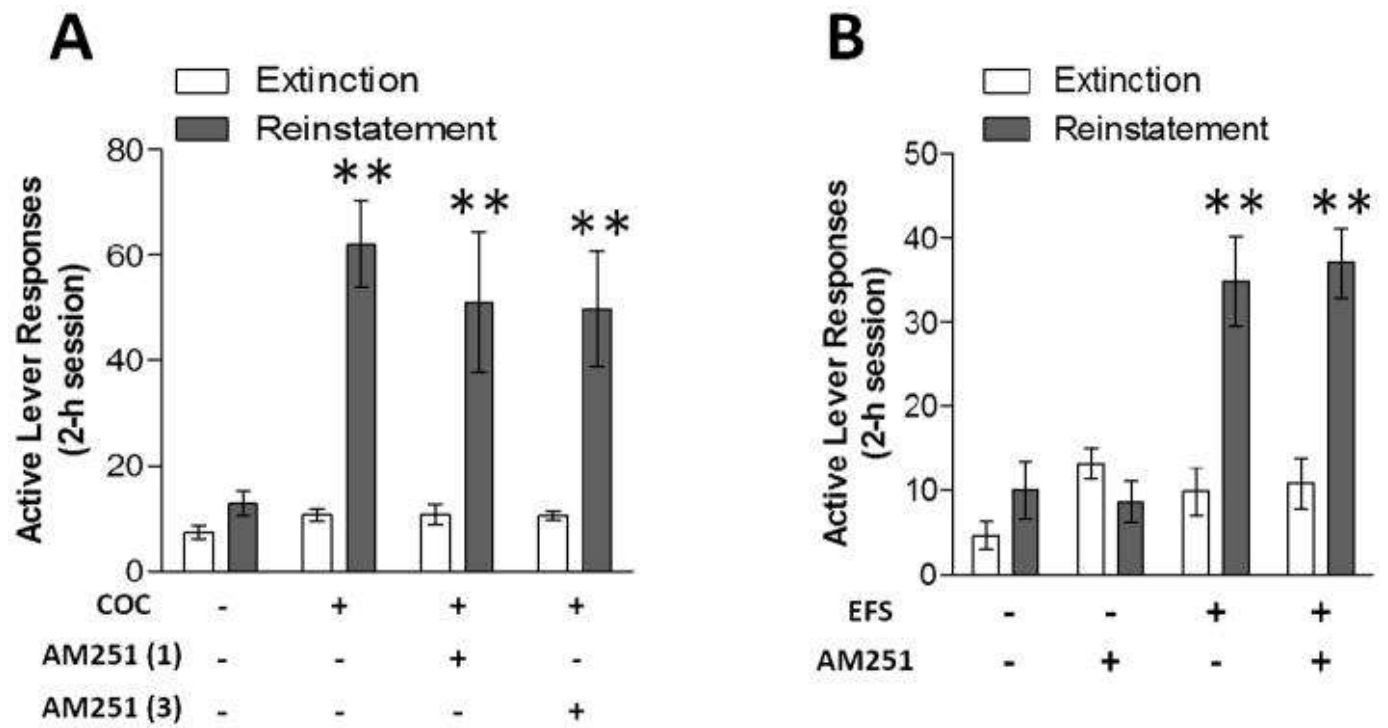

Figure 2. Cocaine-primed or stress-induced reinstatement is not CB1R-dependent. Data represent mean active lever responses ( \pm SEM) during 2-h extinction and reinstatement tests. A. Cocaine-primed reinstatement is observed when rats are given a systemic injection of a high dose of cocaine (COC, $10 \mathrm{mg} / \mathrm{kg}$, i.p.; **p<.01 compared to extinction). Cocaine-primed reinstatement is not significantly attenuated by pre-treatment with the CB1R antagonist, AM251 ( $(n=8), 3(n=8) \mathrm{mg} / \mathrm{kg}$, i.p. $) 30$ min prior to the cocaine injection. B. Stress-induced reinstatement is observed when rats are given electric footshock stress (EFS) for 15 min immediately followed by the reinstatement session in rats with a history of long-access self-administration $(* * p<.01$ compared to extinction). Stress-induced reinstatement is not significantly attenuated by pretreatment with AM251 ( $1 \mathrm{mg} / \mathrm{kg}$, i.p.; $\mathrm{n=5}) 30$ min prior to EFS.

While stress-potentiated reinstatement in short-access rats was blocked by pretreatment with AM251 ( $1 \mathrm{mg} / \mathrm{kg}$, ip), stress-triggered reinstatement in long-access rats was unaffected by the same treatment (Fig 2B). A 2-way repeated measures drug pretreatment (Veh vs AM251) x reinstatement (no footshock vs footshock) ANOVA revealed overall reinstatement effects $\left(F_{(1,4)}=37.16, p<0.01\right)$ but no overall effects of AM251 and no reinstatement x AM251 pretreatment interactions. Post-hoc testing demonstrated that reinstatement was observed in both Veh- $(p<0.01)$, and AM251-pretreated rats $(p<0.01)$ but that reinstatement following vehicle pretreatment was not significantly different from reinstatement following $1 \mathrm{mg} / \mathrm{kg} \mathrm{AM} 251$ $(p>0.05)$. 


\section{Experiment 3: Effect of CB1R antagonism on responding for food and basal locomotor activity}

AM251 at a dose of $3 \mathrm{mg} / \mathrm{kg}$ produced dose-dependent reductions in food-reinforced lever pressing while $1 \mathrm{mg} / \mathrm{kg}$ AM251 was without significant effect (Fig. 3). A one-way repeated measures ANOVA revealed a significant AM251 effect on food-reinforced responding (Veh, $1 \mathrm{mg} / \mathrm{kg}$ AM251, $3 \mathrm{mg} / \mathrm{kg} \mathrm{AM251;} F_{(2,12)}=4.41$, $p<0.05$ ) and post hoc testing demonstrated that pretreatment with 3 $\mathrm{mg} / \mathrm{kg}$, but not $1 \mathrm{mg} / \mathrm{kg}$ AM251 significantly attenuated foodreinforced lever responding compared to vehicle pretreatment $(p<0.05)$.

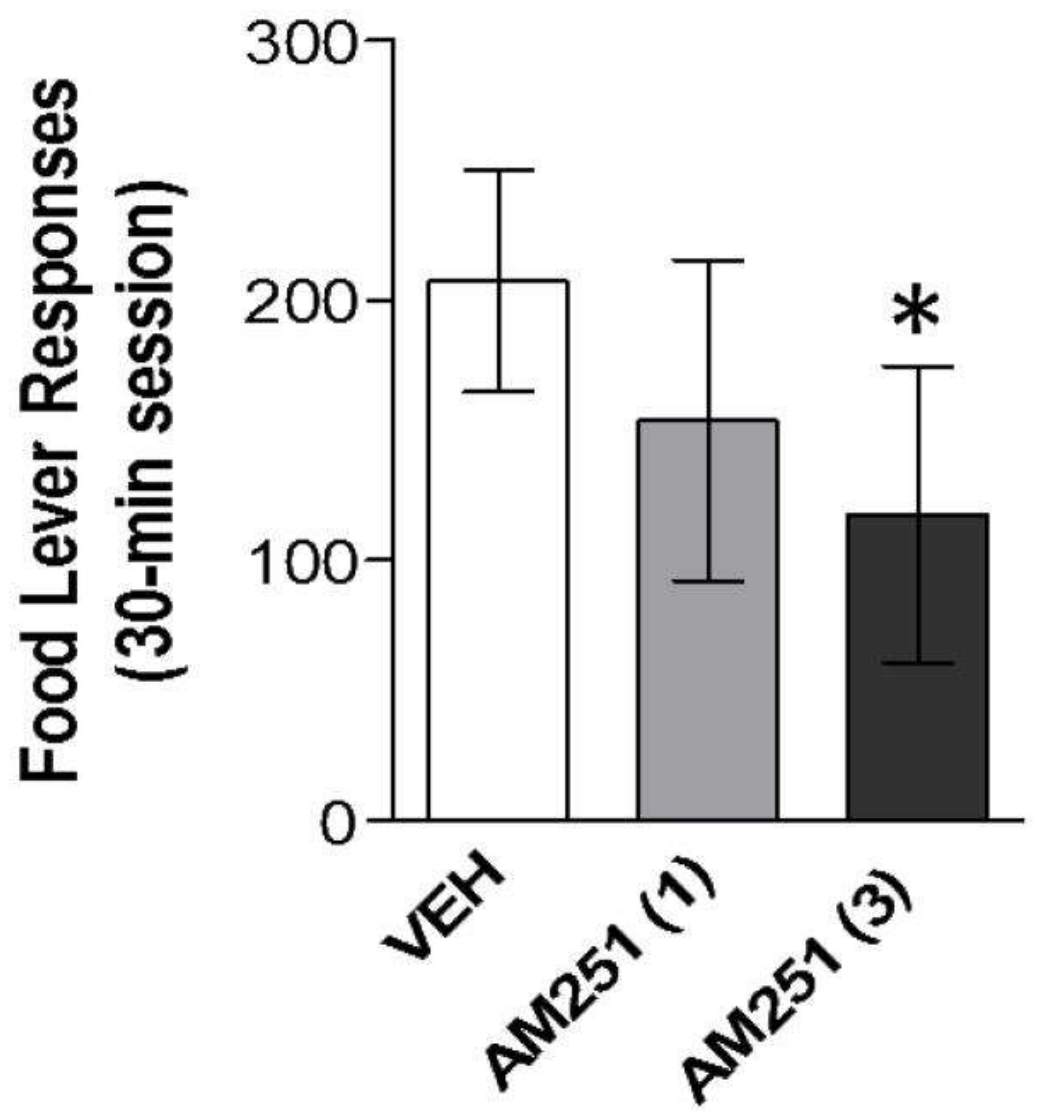

Figure 3. Food-reinforced lever pressing is attenuated by pre-treatment with the CB1R antagonist AM251. Data are presented as mean food lever responses during the 30-min session \pm SEM. Pre-treatment with AM251 30 min prior to the beginning of the session significantly attenuated food-reinforced lever pressing at the higher dose ( 3 $\mathrm{mg} / \mathrm{kg}$, i.p), but not the low dose ( $1 \mathrm{mg} / \mathrm{kg}$, i.p.; $\mathrm{n}=7 ; * \mathrm{p}<.05$ compared to Veh). Each rat received each drug treatment and the order of drug treatment was counterbalanced. 
AM251 effects on basal locomotor activity were tested (Table 2). A one-way repeated measures ANOVA did not reveal a significant effect of the drug (Veh, $1 \mathrm{mg} / \mathrm{kg} \mathrm{AM} 251,3 \mathrm{mg} / \mathrm{kg} \mathrm{AM251)}$ for either total activity $\left(F_{(2,10)}=2.56, p=0.13\right)$ or ambulatory movement $\left(\mathrm{F}_{(2,10)}=0.81, p=0.47\right)$ consistent with previous findings (Adamczyk et al. 2012).

Table 2. Effects of CB1R antagonism on locomotor activity

\begin{tabular}{|c|c|c|c|c|c|c|}
\hline & \multicolumn{2}{|c|}{$1^{\text {st }} \mathbf{3 0} \mathrm{min}$} & \multicolumn{2}{|c|}{$2^{\text {nd }} 30 \mathrm{~min}$} & \multicolumn{2}{|c|}{ Total 1 hr } \\
\hline & Total & Ambulatory & Total & Ambulatory & Total & Ambulatory \\
\hline Vehicle & $\begin{array}{l}1632 \pm \\
286\end{array}$ & $701 \pm 122$ & $611 \pm 138$ & $301 \pm 64$ & $\begin{array}{l}2244 \pm \\
249\end{array}$ & $1003 \pm 122$ \\
\hline $\begin{array}{l}\text { AM251 } \\
\text { (1) }\end{array}$ & $\begin{array}{l}1539 \pm \\
280\end{array}$ & $681 \pm 104$ & $854 \pm 231$ & $323 \pm 75$ & $\begin{array}{l}2393 \pm \\
435\end{array}$ & $1005 \pm 149$ \\
\hline $\begin{array}{l}\text { AM251 } \\
\text { (3) }\end{array}$ & $\begin{array}{l}2058 \pm \\
283\end{array}$ & $776 \pm 114$ & $\begin{array}{l}1391 \pm \\
257\end{array}$ & $484 \pm 70$ & $\begin{array}{l}3450 \pm \\
477\end{array}$ & $1261 \pm 163$ \\
\hline
\end{tabular}

Data represented are mean activity counts \pm SEM for total (total beam breaks) and ambulatory (consecutive beam breaks) activity. The data are presented as activity during the $1^{\text {st }} 30 \mathrm{~min}, 2^{\text {nd }} 30 \mathrm{~min}$, and total $1-\mathrm{h}$ after the injection of either Vehicle (1:1:18 ethanol: Cremaphor: saline) or AM251 (1, $3 \mathrm{mg} / \mathrm{kg}$, i.p.). Systemic administration of AM251 did not significantly affect total or ambulatory activity $(n=6)$ during the 1-h after the injection.

\section{Experiment 4: Effect of footshock stress on endocannabinoid content in the medial prefrontal cortex}

The effects of footshock stress on contents of AEA and 2-AG in subregions of the medial prefrontal cortex were examined in drugnaïve rats euthanized $15 \mathrm{~min}$ after the footshock period ended (Table 3). A 2-way ANOVA with footshock and brain region as factors revealed an overall significant effect of footshock on AEA content $(F(1,36)=8.411 \mathrm{p}<.01)$ and an overall effect of brain region $(F(1,36)=$ $18.10, \mathrm{p}<.001)$ on $2-A G$ content. We also ran planned comparisons in each region for the effect of stress on AEA or 2-AG in each region. Despite trends in each region $A E A$ was not significantly increased in any brain region (PL: $p=0.10$; IL: $p=0.12 ; \mathrm{AC}: p=0.20$ ) but 2-AG content was significantly increased in the $A C$ as a result of stress $(p<.05)$. 
NOT THE PUBLISHED VERSION; this is the author's final, peer-reviewed manuscript. The published version may be accessed by following the link in the citation at the bottom of the page.

Table 3. Effects of footshock stress on endocannabinoid content in subregions of the medial prefrontal cortex

\section{2-AG (nmol/g tissue) Control Shock \\ Shock}

Anterior Cingulate

Prelimbic

Infralimbic
$2.4 \pm 0.6$

$11.0 \pm 1.8$

$4.6 \pm 0.7$
$5.6 \pm 0.5$

$9.6 \pm 1.5$

$5.5 \pm 0.8$
AEA (pmol/g tissue) Control

$8.9 \pm 0.9$

$7.1 \pm 2.7$

$6.3 \pm 1.0$
Shock

$19.3 \pm 5.1$

$17.8 \pm 5.4$

$16.8 \pm 7.1$

Data represented are mean concentrations of the endocannabinoids 2-

arachidonylglycerol (2-AG; nmol/g tissue) and anandamide (AEA; pmol/g tissue) 15 min after termination of a 15 min-footshock $(n=7)$ or in control rats $(n=7)$. There was a significant effect of footshock stress on AEA levels across the 3 brain regions $(p<.001)$. Footshock stress significantly increased $2-A G$ in the anterior cingulate cortex $(p<.05)$ and levels of $2-A G$ in the prelimbic cortex are significantly higher than those in the anterior cingulate or infralimbic $(p<.001)$.

\section{Discussion}

Under conditions where it does not directly trigger relapse, stress can promote responsiveness to other stimuli, thereby "setting the stage" for drug use. We have previously modeled this stagesetting effect using a self-administration/approach in which footshock stress augments cocaine-induced reinstatement in rats (Graf et al. 2013). We reproduced these findings in the present study, demonstrating that, under the self-administration parameters used $(0.5 \mathrm{mg} / \mathrm{kg} / \mathrm{inf} ; 14 \times 2 \mathrm{hrs} /$ day $)$, footshock alone does not reinstate cocaine seeking, but potentiates reinstatement in response to an injection of an otherwise subthreshold dose of cocaine $(2.5 \mathrm{mg} / \mathrm{kg}$, i.p.). We demonstrate that this stage-setting effect of stress is dependent on CB1R signaling. In our paradigm, systemic administration of the CB1R antagonist, AM251, prevents stresspotentiated reinstatement but does not affect reinstatement in response to a priming dose of cocaine $(10 \mathrm{mg} / \mathrm{kg}$, ip) or alter reinstatement triggered by shock alone in rats with a history of cocaine self-administration under long-access (daily 6-h/day) conditions. Moreover, although AM251 also attenuated food-reinforced lever pressing, reductions in reinstatement were observed at an AM251 dose that did not alter food-reinforced responding, while reductions in locomotor activity were not observed at any dose tested.

Endocannabinoid signaling in the brain is stress-responsive and is necessary for stress adaptation and coping (Hill et al. 2011; McLaughlin et al. 2012; McLaughlin et al. 2013; McLaughlin et al. 
2014). There are two subtypes of cannabinoid receptors: CB1 and $\mathrm{CB} 2$. The CB1 receptor is considered to be the predominant cannabinoid receptor in the brain and is expressed in regions critical for motivated behavior, including the prefrontal cortex, nucleus accumbens, and the ventral tegmental area (Devane et al. 1988; Egertova et al. 1998; Herkenham et al. 1991; Melis et al. 2004; Pettit et al. 1998; Wenger et al. 2003), thus positioning CB1Rs as regulators of behavioral processes that enable organisms to effectively respond to stressors and as potential mediators through which stress can influence drug-seeking behavior. Our finding that AM251 prevented the potentiating effects of stress on cocaine-induced reinstatement is consistent with this role for CB1Rs. Moreover, the finding that AM251 did not alter either cocaine-primed or stress-triggered reinstatement in this model suggests that while CB1Rs are important for the interaction between stress and cocaine, they may be less important for the response to either stimuli by itself.

Our study is not the first to examine the contribution of CB1Rs to the reinstatement of extinguished cocaine seeking. De Vries et al. (2001) reported that the CB1R agonist, HU210, reinstated cocaine seeking, while the CB1R antagonist, rimonabant, attenuated cocaineprimed and cue-induced reinstatement but not stress-triggered reinstatement in male Wistar and Long Evans rats. These effects on cocaine-primed reinstatement were reproduced by Xi et al. (2006) and Adamcyzk et al. (2012) using AM251. It is possible that experimental differences, such as rat strains employed (our study is the only one using Sprague Dawley rats), route of administration for the cocaineprime injection, self-administration parameters, or CB1R antagonist pretreatment times and doses underlie the different responses obtained. However, we are not the first to report as others have also reported a lack of effect of CB1R antagonism on cocaine-primed reinstatement. Another study did report attenuation of cocaine-primed reinstatement by AM251 (Filip et al. 2006), but the AM251 dose at which effects were observed in that study $(10 \mathrm{mg} / \mathrm{kg}$, ip) was very high and effects within the AM251 dose range used in the present study were not found. Moreover, Kupferschmidt et al. (2012) found that icv administration of AM251 blocked CRF-induced reinstatement but failed to block footshock- or cocaine-primed reinstatement. In addition, studies using mice have found no effect of CB1R antagonism on cocaine-primed reinstatement following cocaine self-administration 
(Ward et al. 2009) or cocaine-conditioned place preference (Vaughn et al. 2011). Clarification of the precise conditions under which CB1Rs do and do not contribute to cocaine-primed reinstatement will require further investigation. Notably, CB1R antagonists or negative allosteric modulators have also been reported to inhibit on drug-primed heroin (De Vries et al. 2003; Fattore et al. 2005) and methamphetamine (Jing et al. 2014) reinstatement as well cue-induced reinstatement following alcohol (de Bruin et al. 2011), heroin (De Vries et al. 2003), methamphetamine (Jing et al. 2014) and nicotine (De Vries et al. 2005) self-administration. In contrast to our findings, these results suggest that the involvement of CB1Rs in drug seeking may extend beyond the potentiating effects of stress.

Our finding that AM251 fails to block stress-triggered reinstatement is consistent with studies by De Vries et al. (2001) and Kupferschmidt et al. (2012). We previously reported that the mechanisms responsible for stress-triggered reinstatement and those that mediate stress-potentiated reinstatement are distinct. For example, eliminating the corticosterone response to stress has no effect on stress-triggered reinstatement of extinguished cocaine seeking (Erb et al. 1998; Graf et al. 2011), but prevents the ability of stress to potentiate low-dose cocaine-induced reinstatement (Graf et al. 2013). Similar to corticosterone, we observe that the CB1R antagonist AM251 blocked stress-potentiated reinstatement, but not cocaine-primed or stress-triggered reinstatement, suggesting that endocannabinoid involvement in cocaine-seeking behavior in these conditions is also more important for the interaction between stress and cocaine than either stimuli alone. This parallel between corticosterone and endocannabinoids is interesting, considering that corticosterone has been reported to regulate endocannabinoid contents in brain regions that have been implicated in cocaine-seeking behavior (Hill et al. 2011; Kalivas and McFarland 2003; McFarland et al. 2004; Rademacher et al. 2008). For example, restraint stress produces glucocorticoid-dependent increases in the endocannabinoid, 2-AG, in the prelimbic cortex, resulting in a CB1R-dependent attenuation of GABAergic neurotransmission that disinhibits pyramidal neuron outputs (Hill et al. 2011) that likely include a key glutamatergic pathway to the nucleus accumbens core that has been implicated in cocaine-seeking behavior (McFarland et al. 2004). 
In the present study, we observed that footshock stress increased $A E A$ contents in $P L, I L$ and $A C$ subregions of the medial prefrontal cortex and increased 2-AG content in the AC. These results are consistent with prior studies indicating that the prefrontal cortical endocannabinoid system is modulated by stress and anxiety conditions (Hill et al. 2011; McLaughlin et al. 2012; Morena et al. 2014; Rademacher et al. 2008; Roberts et al. 2012). However, prefrontal cortical responses vary in response to different stressors, whereby AEA is decreased following acute restraint (Hill et al. 2011) and swim stress (McLaughlin et al. 2012), or chronic restraint stress (Rademacher et al. 2008), but is increased following a single footshock (Morena et al. 2014), and 2-AG is increased after acute (Hill et al. 2011) or chronic restraint stress (Rademacher et al. 2008). While most stressors result in decreased $A E A$, footshock stress appears unique in eliciting increases in AEA in periaqueductal grey (Hohmann et al. 2005), basolateral amygdala, and dorsal hippocampus (Morena et al. 2014). While it is not presently clear why footshock stress produces unique AEA responses, it is possible that that this increase is observed in part as a consequence of pain mechanisms. These data support a role for footshock stress-induced increases in endocannabinoid content in relevant brain regions though these levels were not examined in rats with a history of cocaine self-administration or under reinstating conditions.

Several pieces of evidence indicate that the effects of AM251 to reduce stress-potentiated reinstatement are not the result of nonspecific motor effects. However to fully examine that possibility, we initially assessed the effects of AM251 on food-reinforced lever pressing. AM251 dose-dependently suppressed food-reinforced responding. However, while the higher AM251 dose tested ( $3 \mathrm{mg} / \mathrm{kg}$ ) reduced both reinstatement and food-reinforced responding, the lower AM251 dose $(1 \mathrm{mg} / \mathrm{kg})$ selectively attenuated stress-potentiated reinstatement. These findings are consistent with prior reports showing significantly lower food-reinforced responding when pre-treated with 3 $\mathrm{mg} / \mathrm{kg}$ but not $1 \mathrm{mg} / \mathrm{kg}$ (Adamczyk et al. 2012). Notably, there is strong evidence for endocannabinoid involvement in feeding, metabolism and obesity (Bellocchio et al. 2006; Kirkham and Tucci 2006; Silvestri and Di Marzo 2013), suggesting that the attenuation of food-reinforced responding represents an effect on appetite, and not a motor effect. Consistent with this possibility, AM251 did not attenuate

Psychopharmacology, Vol 233, No. 1 (January 2016): pg. 99-109. DOI. This article is (C) Springer-Verlag Berlin Heidelberg and permission has been granted for this version to appear in e-Publications@Marquette. Springer-Verlag Berlin Heidelberg does not grant permission for this article to be further copied/distributed or hosted elsewhere without the express permission from Springer-Verlag Berlin Heidelberg. 
cocaine-primed or shock-triggered reinstatement. In order to further assess any potential non-specific motor effects of AM251, we also tested rats for effects of AM251 on locomotor activity. Pre-treatment with AM251 had no significant effect on locomotor activity at either dose, which is also consistent with earlier reports (Adamczyk et al. 2012), suggesting that AM251 effects on reinstatement behavior were not the result of non-specific motor suppression. In fact, there was a trend towards increased locomotor activity at the higher AM251 dose. Taken altogether, our findings suggest that endocannabinoid involvement in stress-potentiated reinstatement is specific to the ability of stress to potentiate the responsiveness to subthreshold reinstating stimuli.

The present findings add to a large body of research implicating endocannabinoid signaling in cocaine addiction (see Wiskerke et al. 2008 for review). Notably, polymorphisms of the gene for the CB1 receptor, CNR1, are associated with cocaine dependence (Clarke et al. 2013; Lopez-Moreno et al. 2012; Zuo et al. 2007; Zuo et al. 2009) and it has been suggested that circulating endocannabinoids may be a viable biomarker for cocaine use disorder in humans (Pavon et al. 2013). Demonstration of a contribution of endocannabinoid signaling to cocaine use in the context of stress may shed additional light on the complex relationship between endocannabinoids and cocaine addiction. While issues related to psychiatric side effects may limit the clinical utility of CB1R antagonists (Christensen et al. 2007), at minimum these data provide mechanistic insight into the processes through which stress influences drug relapse and therefore may guide future treatment approaches.

\section{Acknowledgments}

This research was funded by NIH grant DA015758 to JR Mantsch; NIH grant DA038663 to JR Mantsch and CJ Hillard and by the Research and Education Component of the Advancing a Healthier Wisconsin Endowment at the Medical College of Wisconsin.

\section{Footnotes}

The authors declare no conflicts of interest.

Psychopharmacology, Vol 233, No. 1 (January 2016): pg. 99-109. DOI. This article is (c Springer-Verlag Berlin Heidelberg and permission has been granted for this version to appear in e-Publications@Marquette. Springer-Verlag Berlin Heidelberg does not grant permission for this article to be further copied/distributed or hosted elsewhere without the express permission from Springer-Verlag Berlin Heidelberg. 
NOT THE PUBLISHED VERSION; this is the author's final, peer-reviewed manuscript. The published version may be accessed by following the link in the citation at the bottom of the page.

\section{References}

Adamczyk P, Miszkiel J, McCreary AC, Filip M, Papp M, Przegalinski E. The effects of cannabinoid CB1, CB2 and vanilloid TRPV1 receptor antagonists on cocaine addictive behavior in rats. Brain Res. 2012;1444:45-54.

Bellocchio L, Mancini G, Vicennati V, Pasquali R, Pagotto U. Cannabinoid receptors as therapeutic targets for obesity and metabolic diseases. Curr Opin Pharmacol. 2006;6:586-91.

Blacktop JM, Seubert C, Baker DA, Ferda N, Lee G, Graf EN, Mantsch JR. Augmented cocaine seeking in response to stress or CRF delivered into the ventral tegmental area following long-access self-administration is mediated by CRF receptor type 1 but not CRF receptor type 2. $J$ Neurosci. 2011;31(31):11396-403.

Brusco A, Tagliaferro PA, Saez T, Onaivi ES. Ultrastructural localization of neuronal brain CB2 cannabinoid receptors. Ann $N$ Y Acad Sci. 2008;1139:450-7.

Buffalari DM, See RE. Footshock stress potentiates cue-induced cocaineseeking in an animal model of relapse. Physiol Behav. 2009;98:614-7.

Capriles N, Rodaros D, Sorge RE, Stewart J. A role for the prefrontal cortex in stress- and cocaine-induced reinstatement of cocaine seeking in rats. Psychopharmacology (Berl) 2003;168:66-74.

Christensen R, Kristensen PK, Bartels EM, Bliddal H, Astrup A. Efficacy and safety of the weight-loss drug rimonabant: a meta-analysis of randomised trials. Lancet. 2007;370:1706-13.

Clarke TK, Bloch PJ, Ambrose-Lanci LM, Ferraro TN, Berrettini WH, Kampman KM, Dackis CA, Pettinati HM, O'Brien CP, Oslin DW, Lohoff FW. Further evidence for association of polymorphisms in the CNR1 gene with cocaine addiction: confirmation in an independent sample and metaanalysis. Addict Biol. 2013;18:702-8.

Coffey SF, Saladin ME, Drobes DJ, Brady KT, Dansky BS, Kilpatrick DG. Trauma and substance cue reactivity in individuals with comorbid posttraumatic stress disorder and cocaine or alcohol dependence. Drug Alcohol Depend. 2002;65:115-27.

de Bruin NM, Lange JH, Kruse CG, Herremans AH, Schoffelmeer AN, van Drimmelen M, De Vries TJ. SLV330, a cannabinoid CB(1) receptor antagonist, attenuates ethanol and nicotine seeking and improves inhibitory response control in rats. Behav Brain Res. 2011;217:40815.

De La Garza R, 2nd, Ashbrook LH, Evans SE, Jacobsen CA, Kalechstein AD, Newton TF. Influence of verbal recall of a recent stress experience on anxiety and desire for cocaine in non-treatment seeking, cocaineaddicted volunteers. Am J Addict. 2009;18:481-7. 
NOT THE PUBLISHED VERSION; this is the author's final, peer-reviewed manuscript. The published version may be accessed by following the link in the citation at the bottom of the page.

De Vries TJ, de Vries W, Janssen MC, Schoffelmeer AN. Suppression of conditioned nicotine and sucrose seeking by the cannabinoid-1 receptor antagonist SR141716A. Behav Brain Res. 2005;161:164-8.

De Vries TJ, Homberg JR, Binnekade R, Raaso H, Schoffelmeer AN. Cannabinoid modulation of the reinforcing and motivational properties of heroin and heroin-associated cues in rats. Psychopharmacology (Berl) 2003;168:164-9.

De Vries TJ, Shaham Y, Homberg JR, Crombag H, Schuurman K, Dieben J, Vanderschuren LJ, Schoffelmeer AN. A cannabinoid mechanism in relapse to cocaine seeking. Nat Med. 2001;7:1151-4.

Devane WA, Dysarz FA, 3rd, Johnson MR, Melvin LS, Howlett AC. Determination and characterization of a cannabinoid receptor in rat brain. Mol Pharmacol. 1988;34:605-13.

Duncan E, Boshoven W, Harenski K, Fiallos A, Tracy H, Jovanovic T, Hu X, Drexler K, Kilts $\mathrm{C}$. An fMRI study of the interaction of stress and cocaine cues on cocaine craving in cocaine-dependent men. Am J Addict. 2007;16:174-82.

Egertova M, Giang DK, Cravatt BF, Elphick MR. A new perspective on cannabinoid signalling: complementary localization of fatty acid amide hydrolase and the CB1 receptor in rat brain. Proc Biol Sci. $1998 ; 265: 2081-5$.

Erb S, Shaham Y, Stewart J. The role of corticotropin-releasing factor and corticosterone in stress- and cocaine-induced relapse to cocaine seeking in rats. J Neurosci. 1998;18(14):5529-36.

Fattore L, Spano S, Cossu G, Deiana S, Fadda P, Fratta W. Cannabinoid CB(1) antagonist SR $141716 \mathrm{~A}$ attenuates reinstatement of heroin selfadministration in heroin-abstinent rats. Neuropharmacology. 2005;48:1097-1104.

Feltenstein MW, See RE. Potentiation of cue-induced reinstatement of cocaine-seeking in rats by the anxiogenic drug yohimbine. Behav Brain Res. 2006;174:1-8.

Furnari M, Epstein DH, Phillips KA, Jobes ML, Kowalczyk WJ, Vahabzadeh M, Lin $\mathrm{JL}$, Preston KL. Some of the people, some of the time: field evidence for associations and dissociations between stress and drug use. Psychopharmacology (Berl) 2015

Graf EN, Hoks MA, Baumgardner J, Sierra J, Vranjkovic O, Bohr C, Baker DA, Mantsch JR. Adrenal activity during repeated long-access cocaine selfadministration is required for later CRF-Induced and CRF-dependent stressor-induced reinstatement in rats. Neuropsychopharmacology. 2011;36:1444-54.

Graf EN, Wheeler RA, Baker DA, Ebben AL, Hill JE, McReynolds JR, Robble MA, Vranjkovic O, Wheeler DS, Mantsch JR, Gasser PJ. Corticosterone acts in the nucleus accumbens to enhance dopamine signaling and

Psychopharmacology, Vol 233, No. 1 (January 2016): pg. 99-109. DOI. This article is (C Springer-Verlag Berlin Heidelberg and permission has been granted for this version to appear in e-Publications@Marquette. Springer-Verlag Berlin Heidelberg does not grant permission for this article to be further copied/distributed or hosted elsewhere without the express permission from Springer-Verlag Berlin Heidelberg. 
NOT THE PUBLISHED VERSION; this is the author's final, peer-reviewed manuscript. The published version may be accessed by following the link in the citation at the bottom of the page.

potentiate reinstatement of cocaine seeking. $J$ Neurosci. 2013;33:11800-10.

Herkenham M, Lynn AB, Johnson MR, Melvin LS, de Costa BR, Rice KC. Characterization and localization of cannabinoid receptors in rat brain: a quantitative in vitro autoradiographic study. $J$ Neurosci. $1991 ; 11: 563-83$.

Hill MN, McLaughlin RJ, Pan B, Fitzgerald ML, Roberts CJ, Lee TT, Karatsoreos IN, Mackie K, Viau V, Pickel VM, McEwen BS, Liu QS, Gorzalka BB, Hillard $\mathrm{CJ}$. Recruitment of prefrontal cortical endocannabinoid signaling by glucocorticoids contributes to termination of the stress response. $J$ Neurosci. 2011;31:10506-15.

Hill MN, Patel S, Campolongo P, Tasker JG, Wotjak CT, Bains JS. Functional interactions between stress and the endocannabinoid system: from synaptic signaling to behavioral output. J Neurosci. 2010;30:14980-6. Hohmann AG, Suplita RL, Bolton NM, Neely MH, Fegley D, Mangieri R, Krey JF, Walker JM, Holmes PV, Crystal JD, Duranti A, Tontini A, Mor M, Tarzia G, Piomelli D. An endocannabinoid mechanism for stressinduced analgesia. Nature. 2005;435:1108-1112.

Howlett AC, Barth F, Bonner TI, Cabral G, Casellas P, Devane WA, Felder CC, Herkenham M, Mackie K, Martin BR, Mechoulam R, Pertwee RG. International Union of Pharmacology. XXVII. Classification of cannabinoid receptors. Pharmacological reviews. 2002;54:161-202.

Jing L, Qiu Y, Zhang Y, Li JX. Effects of the cannabinoid CB(1) receptor allosteric modulator ORG 27569 on reinstatement of cocaine- and methamphetamine-seeking behavior in rats. Drug Alcohol Depend. 2014;143:251-6.

Kalivas PW, McFarland K. Brain circuitry and the reinstatement of cocaineseeking behavior. Psychopharmacology (Berl) 2003;168:44-56.

Kirkham TC, Tucci SA. Endocannabinoids in appetite control and the treatment of obesity. CNS Neurol Disord Drug Targets. 2006;5:27292.

Kupferschmidt DA, Klas PG, Erb S. Cannabinoid CB1 receptors mediate the effects of corticotropin-releasing factor on the reinstatement of cocaine seeking and expression of cocaine-induced behavioural sensitization. Br J Pharmacol. 2012;167:196-206.

Lopez-Moreno JA, Echeverry-Alzate V, Buhler KM. The genetic basis of the endocannabinoid system and drug addiction in humans. $J$ Psychopharmacol. 2012;26:133-43.

Mantsch JR, Baker DA, Francis DM, Katz ES, Hoks MA, Serge JP. Stressor- and corticotropin releasing factor-induced reinstatement and active stressrelated behavioral responses are augmented following long-access cocaine self-administration by rats. Psychopharmacology (Berl) 2008a;195:591-603.

Psychopharmacology, Vol 233, No. 1 (January 2016): pg. 99-109. DOI. This article is @ Springer-Verlag Berlin Heidelberg and permission has been granted for this version to appear in e-Publications@Marquette. Springer-Verlag Berlin Heidelberg does not grant permission for this article to be further copied/distributed or hosted elsewhere without the express permission from Springer-Verlag Berlin Heidelberg. 
Mantsch JR, Baker DA, Serge JP, Hoks MA, Francis DM, Katz ES. Surgical adrenalectomy with diurnal corticosterone replacement slows escalation and prevents the augmentation of cocaine-induced reinstatement in rats self-administering cocaine under long-access conditions. Neuropsychopharmacology. 2008b;33:814-26.

Mantsch JR, Goeders NE. Ketoconazole does not block cocaine discrimination or the cocaine-induced reinstatement of cocaine-seeking behavior. Pharmacol Biochem Behav. 1999;64:65-73.

Mantsch JR, Yuferov V, Mathieu-Kia AM, Ho A, Kreek MJ. Effects of extended access to high versus low cocaine doses on self-administration, cocaine-induced reinstatement and brain mRNA levels in rats. Psychopharmacology (Berl) 2004;175:26-36.

McFarland K, Davidge SB, Lapish CC, Kalivas PW. Limbic and motor circuitry underlying footshock-induced reinstatement of cocaine-seeking behavior. J Neurosci. 2004;24:1551-60.

McLaughlin RJ, Hill MN, Bambico FR, Stuhr KL, Gobbi G, Hillard CJ, Gorzalka BB. Prefrontal cortical anandamide signaling coordinates coping responses to stress through a serotonergic pathway. Eur Neuropsychopharmacol. 2012;22:664-71.

McLaughlin RJ, Hill MN, Dang SS, Wainwright SR, Galea LA, Hillard CJ, Gorzalka BB. Upregulation of $\mathrm{CB}(1)$ receptor binding in the ventromedial prefrontal cortex promotes proactive stress-coping strategies following chronic stress exposure. Behav Brain Res. 2013;237:333-7.

McLaughlin RJ, Hill MN, Gorzalka BB. A critical role for prefrontocortical endocannabinoid signaling in the regulation of stress and emotional behavior. Neurosci Biobehav Rev. 2014;42C:116-131.

McReynolds JR, Pena DF, Blacktop JM, Mantsch JR. Neurobiological mechanisms underlying relapse to cocaine use: contributions of CRF and noradrenergic systems and regulation by glucocorticoids. Stress. 2014;17:22-38.

Melis M, Pistis M, Perra S, Muntoni AL, Pillolla G, Gessa GL. Endocannabinoids mediate presynaptic inhibition of glutamatergic transmission in rat ventral tegmental area dopamine neurons through activation of CB1 receptors. J Neurosci. 2004;24:53-62.

Morena M, Roozendaal B, Trezza V, Ratano P, Peloso A, Hauer D, Atsak P, Trabace L, Cuomo V, McGaugh JL, Schelling G, Campolongo P. Endogenous cannabinoid release within prefrontal-limbic pathways affects memory consolidation of emotional training. Proc Natl Acad Sci USA. 2014;111(51):18333-8.

Onaivi ES. Commentary: Functional Neuronal CB2 Cannabinoid Receptors in the CNS. Curr Neuropharmacol. 2011;9:205-8.

Psychopharmacology, Vol 233, No. 1 (January 2016): pg. 99-109. DOI. This article is (c Springer-Verlag Berlin Heidelberg and permission has been granted for this version to appear in e-Publications@Marquette. Springer-Verlag Berlin Heidelberg does not grant permission for this article to be further copied/distributed or hosted elsewhere without the express permission from Springer-Verlag Berlin Heidelberg. 
Onaivi ES, Ishiguro $H$, Gong JP, Patel S, Perchuk A, Meozzi PA, Myers L, Mora Z, Tagliaferro P, Gardner E, Brusco A, Akinshola BE, Liu QR, Hope B, Iwasaki S, Arinami T, Teasenfitz L, Uhl GR. Discovery of the presence and functional expression of cannabinoid CB2 receptors in brain. Ann $N$ Y Acad Sci. 2006;1074:514-36.

Patel S, Rademacher DJ, Hillard CJ. Differential regulation of the endocannabinoids anandamide and 2-arachidonoylglycerol in the limbic forebrain by dopamine receptor activity. J Pharmacol Exp Ther. 2003;306(3):880-8.

Pavon FJ, Araos P, Pastor A, Calado M, Pedraz M, Campos-Cloute R, Ruiz JJ, Serrano A, Blanco E, Rivera P, Suarez J, Romero-Cuevas M, Pujadas M, Vergara-Moragues E, Gornemann I, Torrens M, de la Torre R, Rodriguez de Fonseca F. Evaluation of plasma-free endocannabinoids and their congeners in abstinent cocaine addicts seeking outpatient treatment: impact of psychiatric co-morbidity. Addict Biol. 2013;18:955-69.

Pertwee RG. Pharmacology of cannabinoid CB1 and CB2 receptors. Pharmacol Ther. 1997;74:129-80.

Pertwee RG, Ross RA. Cannabinoid receptors and their ligands. Prostaglandins Leukot Essent Fatty Acids. 2002;66:101-21.

Peters J, LaLumiere RT, Kalivas PW. Infralimbic prefrontal cortex is responsible for inhibiting cocaine seeking in extinguished rats. $J$ Neurosci. 2008;28:6046-53.

Pettit DA, Harrison MP, Olson JM, Spencer RF, Cabral GA. Immunohistochemical localization of the neural cannabinoid receptor in rat brain. J Neurosci Res. 1998;51:391-402.

Preston $\mathrm{KL}$, Epstein DH. Stress in the daily lives of cocaine and heroin users: relationship to mood, craving, relapse triggers, and cocaine use. Psychopharmacology (Berl) 2011;218:29-37.

Rademacher DJ, Meier SE, Shi L, Ho WS, Jarrahian A, Hillard CJ. Effects of acute and repeated restraint stress on endocannabinoid content in the amygdala, ventral striatum, and medial prefrontal cortex in mice. Neuropharmacology. 2008;54:108-16.

Roberts CJ, Stuhr KL, Hillard CJ. Swim stress differentially affects limbic contents of 2-arachidonoylglycerol and 2-oleoylglycerol. Neuroscience. 2012;204:74-82.

Shaham Y, Erb S, Stewart J. Stress-induced relapse to heroin and cocaine seeking in rats: a review. Brain Res Brain Res Rev. 2000;33:13-33.

Sidhpura N, Parsons LH. Endocannabinoid-mediated synaptic plasticity and addiction-related behavior. Neuropharmacology. 2011;61:1070-87.

Silvestri C, Di Marzo V. The endocannabinoid system in energy homeostasis and the etiopathology of metabolic disorders. Cell Metab. 2013;17:475-90.

Psychopharmacology, Vol 233, No. 1 (January 2016): pg. 99-109. DOI. This article is @ Springer-Verlag Berlin Heidelberg and permission has been granted for this version to appear in e-Publications@Marquette. Springer-Verlag Berlin Heidelberg does not grant permission for this article to be further copied/distributed or hosted elsewhere without the express permission from Springer-Verlag Berlin Heidelberg. 
NOT THE PUBLISHED VERSION; this is the author's final, peer-reviewed manuscript. The published version may be accessed by following the link in the citation at the bottom of the page.

Sinha R. Modeling stress and drug craving in the laboratory: implications for addiction treatment development. Addict Biol. 2009;14:84-98.

Vaughn LK, Mantsch JR, Vranjkovic O, Stroh G, Lacourt M, Kreutter M, Hillard $\mathrm{CJ}$. Cannabinoid receptor involvement in stress-induced cocaine reinstatement: potential interaction with noradrenergic pathways. Neuroscience. 2012;204:117-24.

Vranjkovic O, Gasser PJ, Gerndt CH, Baker DA, Mantsch JR. Stress-induced cocaine seeking requires a beta- 2 adrenergic receptor-regulated pathway from the ventral bed nucleus of the stria terminalis that regulates CRF actions in the ventral tegmental area. $J$ Neurosci. 2014;34(37):12504-14.

Ward SJ, Rosenberg M, Dykstra LA, Walker EA. The CB1 antagonist rimonabant (SR141716) blocks cue-induced reinstatement of cocaine seeking and other context and extinction phenomena predicitve of relapse. Drug Alcohol Depend. 2009;105:248-55.

Wenger T, Moldrich G, Furst $S$. Neuromorphological background of cannabis addiction. Brain Res Bull. 2003;61:125-8.

Wiskerke J, Pattij T, Schoffelmeer AN, De Vries TJ. The role of CB1 receptors in psychostimulant addiction. Addict Biol. 2008;13:225-38.

Xi ZX, Gilbert JG, Peng XQ, Pak AC, Li X, Gardner EL. Cannabinoid CB1 receptor antagonist $A M 251$ inhibits cocaine-primed relapse in rats: role of glutamate in the nucleus accumbens. J Neurosci. 2006;26:8531-6.

Zuo L, Kranzler HR, Luo X, Covault J, Gelernter J. CNR1 variation modulates risk for drug and alcohol dependence. Biol Psychiatry. 2007;62:61626.

Zuo L, Kranzler HR, Luo X, Yang BZ, Weiss R, Brady K, Poling J, Farrer L, Gelernter J. Interaction between two independent CNR1 variants increases risk for cocaine dependence in European Americans: a replication study in family-based sample and population-based sample. Neuropsychopharmacology. 2009;34:1504-13.

Corresponding Author: John Mantsch, Department of Biomedical Sciences, Marquette University, Email: john.mantsch@marquette.edu, Telephone Number: (414) 288-2036, Fax Number: (414) 288-6564

Psychopharmacology, Vol 233, No. 1 (January 2016): pg. 99-109. DOI. This article is (C Springer-Verlag Berlin Heidelberg and permission has been granted for this version to appear in e-Publications@Marquette. Springer-Verlag Berlin Heidelberg does not grant permission for this article to be further copied/distributed or hosted elsewhere without the express permission from Springer-Verlag Berlin Heidelberg. 